\title{
LINGUISTIC ERRORS OF BRAZILIAN STUDENTS WHEN LEARNING RUSSIAN AS A FOREIGN LANGUAGE (BASIC LEVEL)
}

\author{
Joao Paulo Sabadin Santos T. Medina \\ Brazil \\ Suellen Martins Medina \\ Brazil \\ Ekaterina A. Budnik \\ Pushkin State Russian language Institute, Russian Federation
}

\begin{abstract}
The article examines the errors in the basic level regarding the interference of the Portuguese language when Brazilian students learn Russian as a foreign language and offers the methodic to predict and avoid them. For this, authors compare the phonetic systems of Russian and Brazilian Portuguese as well as the main grammar units and structures that form the linguistic minimum on the basic level. Then, using the comparative analysis the errors in the students' speech are predicted and interpreted. The results of theoretical comparison are compared to the actual and real errors. In the phonetic plan authors figure out significant difference in the signs of hardness, softness, place of articulation, mode of articulation and nasalization, and not big difference in acoustic signs and duration of sounds. In the grammatical field the results point out to a new and optimal order in teaching the cases. Also the necessity to adapt different grammar understanding of Russian verbal structure to the Brazilian one is described regarding the preposition and type of complement and the verb aspects. Authors developed exercises to help students overcome such errors more efficiently and in less time.
\end{abstract}

Keywords: Brazilian Portuguese, comparative study, grammar interference, phonetic interference, Russian as a foreign language.

\section{Introduction}

The methodology of teaching Russian as a foreign language (RFL) to Brazilian students is poorly developed in Brazilian scientific literature as well as in Russian. This area is lack of scientific works and studies, the main sources of cross-language comparisons are, firstly, Russian language textbooks for a Brazilian audience, secondly, materials for teaching the Portuguese language for Russians, including analysis of Russian interference in learning Portuguese; and thirdly, comparisons between Russian and Romance languages, an approach that 
Medina et al., 2020. Linguistic Errors of Brazilian Students when Learning

Russian as a Foreign Language (Basic Level)

already has a rich tradition and can serve as an example for our study. Taking into account the contribution of each of these sources allows us to begin the comparison between Russian and Portuguese for educational purposes not from scratch, but based on work whose object intersects with ours.

\section{Literature review}

The analysis of four textbooks published in the $20^{\text {th }}$ century indicates the urgent need for new materials for teaching Brazilian audience RFL. The first two textbooks could hardly have been used in the educational process: Marina Dolenga's "Self-Tutorial of Russian" (Dolenga, 1955) is a book based on the grammatically-translated concept of teaching a foreign language. Oliveira's "Russian language course" (Oliveira, n. d.) does not comply with the methodological aspect of the presentation of the material and often contains unsuccessful examples from the point of view of RFL teaching methods. The other two textbooks, in their turn, contain good teaching material and, despite the above shortcomings, are a valuable contribution for teaching RFL to Brazilians: N. Potapova's "Short Russian Language Course" is limited in the development of teaching methods for its time; despite this, it not only adheres quite well to the principles of the teaching methods of RFL of that time, but also provides the student with accurate and neatly constructed grammar material (Potapova, 1961). However, the vocabulary in the manual clearly exceeds the lexical minimum for the basic level (A1-A2), the number of exercises is not enough to master the presented rules and, most important, the presentation of the material does not correspond to the learning possibilities of students. T. Castro's "Speak Russian" is more diverse and well elaborated in terms of the proposed exercises and vocabulary, but makes elementary and unacceptable methodological errors, especially in explaining grammatical phenomena (Castro, 2005). In all of them the phonetic explanations lack minimally efficient methods.

Professional teaching Portuguese to Russian students has been developing for several decades. This tradition contributes to the emergence of theoretical works on interlingual interference. Despite the lack of a systematic analysis of the structural differences between the Russian and Portuguese languages (Petrova, 2016, p. 2), valuable approaches to this problem are already encountered in scientific papers but very few.

Separately, we emphasize the successful implementation of comparisons between Russian and European languages for teaching RFL. Comparative analyzes described in the works by V.G. Gak (2006) and V. N. Wagner (2001) are valuable examples of such a linguistic comparison between languages, as well as its usage for educational purposes. 
Regarding the phonetic aspects, there is a vast tradition of teaching then to foreign students. An important contribution to our approach is the numerous works by E.A. Budnik (2007, 2009) on phonetical interference of the native language of Portuguese speakers in their Russian speech; nevertheless, works on the dialectal interference of Brazilian students when learning the target language are still to be made. Also, the phonetical variation of Brazilian dialects is explored by T.C. Silva and Bearzotti Filho (Silva, 2003; Bearzotti Filho, 2002).

E.M. Vereshhagin and V.G. Kostomarov's contribution to the development of methods of teaching Russian as a foreign language is undeniable. In their works, they expand the understanding of the language including the cultural components, i.e. when a reader/student considers culture and language as interconnected systems. In this regard, they recognize the importance of taking into account the native language of students during the study of a foreign language: "the acquisition of any other language can only occur if there is the interaction of the native and non-native languages" (Vereshhagin \& Kostomarov, 1990, p. 112).

These scholars also emphasize the importance of orienting grammatical comparisons to educational goals, which provide theoretical basis to the comparative material. However, for learning purposes, the mother tongue and the target language should be compared in a well-defined way. That is why traditional grammars, known as comparative grammars, cannot be a sufficient linguistic basis for learning. It is needed a description that is specifically focused on training (Vereshhagin \& Kostomarov, 1990, p. 113).

Another important point is the fact that the territorial-dialectal affiliation of the speaker affects his speech. This applies not only to the native language proficiency, but also to the non-native language proficiency. We describe the linguistic circumstances of the Portuguese language in Brazil: historical prerequisites for the Brazilian Portuguese language (BP) formation allows us to assert that when teaching Russian as a foreign language (RFL) Portuguese and Brazilians students are required different approaches and methodological methods for vocabulary, grammar and phonetics study.

As a result of complex factors, including not only linguistic, but also related to cultural and political aspects, a comparison of the Portuguese dialects at the present stage of their development indicates phonetic and lexicalgrammatical differences, which clearly affects the development in a foreign language and, consequently, should speak out for building a nationally oriented approach. The features of the Portuguese language in Brazil indicate the phonetic variability in the dialects that makes the methodologist and teacher of RFL take into account the Brazilian student's region of origin in order to better understand and correct mistakes. 
Medina et al., 2020. Linguistic Errors of Brazilian Students when Learning

Russian as a Foreign Language (Basic Level)

In this article we analyze the grammatical and the phonetic interference not only of the native language per se, but also of the dialect of the Brazilian students when they are acquiring a target language - Russian. Such study has never been done before.

\section{Methodology}

Comparative and descriptive methods were used in the work, along with linguistic analysis. The results of comparative linguistic analysis serve as a reliable scientifically based linguodidactic base for teaching the target language, as well as taking into account the structural features of the native and studied languages gives the teacher fairly accurate objective data for predicting, forecasting and solving the methodological problems that arise when teaching a particular audience (Arakin, 1989, p. 4).

Comparative system analysis of two languages, native and target, refers to a linguistic typology.

In our study, the comparison between Russian (the target language) and BP (mother tongue) is made in three microsystems: morphology, syntax, and phonetics. The analyzed categories are determined in accordance with the Wagner's concept of linguodidactic common units, which are specific determinants to represent linguistic material. They are identified on the basis of the nature of the linguistic phenomenon itself and the nature of interlanguage relations of similarity, difference or partial mismatch, established according to a comparative analysis of linguistic facts and analysis of typical errors.

The phonetic interference data was collected during individual lessons with the adult students. They were given a list of words in Russian for reading. Their speech was recorded and then transcribed and compared to native Russian sounds. Some of students live in Brazil and another part learn the target language in Russia. The grammar interference data was collected when checking students' essays and text retelling.

\section{Research results}

1. Phonetic aspects

A conscious comparison of the phonetic composition (PC) and the articulation basis (AB) of the native and target languages is the main way of teaching foreign phonetics instead of the "direct" teaching method, a position which is confirmed by the classics of the Russian methodology of teaching foreign languages. Only with the systematic presentation of phonological means of the language and the detailed organization of the articulation stream does the 
learning process help students achieve specific results when teaching oral speech in a foreign language.

When describing the $\mathrm{PC}$ and $\mathrm{AB}$ of the Russian language and $\mathrm{BP}$, significantly different phonological systems are observed, the difference of which will necessarily be observed in the process of mastering the phonetic structure of the Russian language by a Brazilian student.

The role of phonetics and intonation in the process of mastering Russian as a foreign language is very significant. Setting the correct pronunciation makes it possible to communicate in any living language; in this way lexical and grammatical skills are formed, as well as speaking, listening and writing skills in a foreign language. Audio interference and the corresponding foreign accent in speech in a foreign language is based on differences in the sound structure of the languages in contact. According to the classification of $\mathrm{U}$. Weinreich, the division of interference into types when analyzing its phenomena in the secondary phonetic system is as follows: phonemic under-differentiation, overdifferentiation, reinterpretation of distinction, substitution of speech sounds (actual phone substitution) (Weinreich, 1972).

The consistency and predictability of phonetic speech disorders in a foreign language makes it possible to eliminate errors when using conscious reliance on the native language (emphasis prediction) (Weinreich, 1972, p. 174). Potential phonetic errors of Brazilian students studying RFL are associated with the presence of sounds in the Russian that are not in the BP, but the most important problem is the unusual BP combinations of sounds in syllables.

A comparison of the consonant systems of the Russian language and BP allows us to predict the potential sound interference in the reproduction of consonants. Based on a phonological comparison, possible interference and a real accent were identified. Significant differences are noted in the signs of hardness-softness and place of articulation; as a consequence, not only an accent is possible in the Russian language of the Brazilians, but also phonological errors.

The most common interference of the native language of Brazilians is observed in violation of soft sounds, which can lead to a phonetic error based on substitution and, consequently, to the phonological replacement of soft consonants with hard ones due to the undifferentiation of these phonemes:

Днём 'in the afternoon - $\partial[\mathrm{n}] \ddot{е м}$, день'day' - де[n], жизнь 'life' - жиз[n], соль 'salt' - со[l], фильм 'film' - фи[l]м, цель 'objective' - це[l], национальный 'national' - национа[l]ный.

There is also the addition of a vowel in an attempt to reproduce soft consonants: 
Medina et al., 2020. Linguistic Errors of Brazilian Students when Learning Russian as a Foreign Language (Basic Level)

Tempadb 'notebook' - mempa[di $]$, nemb 'to sing' - ne[ $\left.\mathrm{t}_{\mathrm{I}}\right]$, padocmb

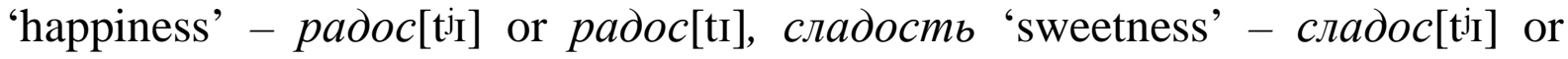

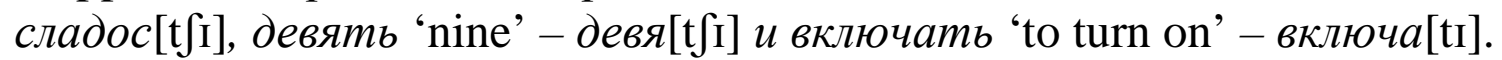

The second group of errors points out to the tendency of adding the vowel [I] in the attempt to reproduce the soft consonants. We propose the following exercises are aimed to overcome it:

Ex. 1. Read out loud:

Ты, дядя, тетя, тип, две, сидеть, дети, петь, ходить, вот, кот

Ex. 2. Repeat after the teacher, write these words:

Площадь, мыть, будь, гвоздь, ходить, лауреат, вот, дождь

Ex. 3. Separate the read words by sign: softness $\left(\mathrm{T}^{\prime}\right)-\left(\mathrm{д}^{\prime}\right)$ or hardness $(\mathrm{T})-$ (д).

Мать, двести, говорить, кот, площадь, лошадь, пить, дядя, твердьй.

The Russian $u-[6:], u-[\widetilde{\mathrm{ts}}]$ and $x-[\mathrm{x}]$ do not have the corresponding sounds in BP. The first sound, a dorsal prepalatal soft, is pronounced as hard by a Brazilian student: вообще 'in general' - вооб[s]e, пища 'food' - $n u[\mathrm{~s}] a$, щъи 'cabbage soup' - [s] $]$ (over-differentiation) or even as an affricate (which sound

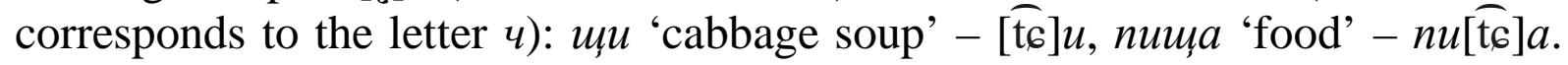
The second case of interference can be associated the existence of the affricate consonant in BP.

Ex. 1. Listen and repeat:

Щи, щётка, щёки, вещь, площадь, ищи, вообще, борщ, сгущёнка.

Ex. 2. Separate the following words in two columns: with hard $ш$ and with soft щ.

Щётка, шахтёр, шкаф, чашка, карандаш, щеёки, шарф, щедро, вещь

The affricate $u-[\mathrm{ts}]$ is frequently pronounced by Brazilian students as

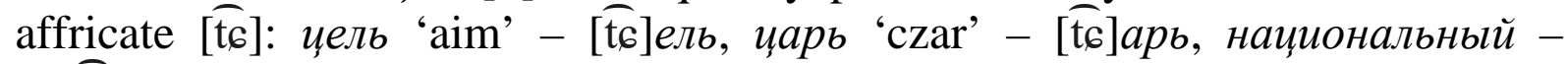
на[โ厄] [s]арь оr [S]арь; национальный - на[Г]иональный.

Ex. 1. Read the words:

Цирк, иентр, иарь, иена, иыган, отеи, танец, бразилеи, молодеи

Ex. 2. Read the words paying attention to the sounds of с and ц.

Нос-танец; сон-танцор; несу - отиу; носы - концы; такси-цирк.

The third sound, 1-focus fricative, is of particular interest. It will be pronounced correctly, like a hard velar posterior [x]: xopomo 'good' [x]орошо, хлеб 'bread' - [x]леб, холодно 'cold' - [x]олодно, хозяин 'owner' [x]озяин, but incorrectly, when the Russian word corresponds to a soft velar posterior $\left[\mathrm{x}^{\mathrm{j}}\right]$ : химия 'chemics' - [x]имия and хитрый 'clever' - [x]итрый. However, this coincidence only happens if this sound is present in the student's native phonetic system, in which there is great variability depending on the dialect, especially with respect to these two sounds. 
Only by considering the dialectal influence can we fully understand the corresponding interference.

Due to the fact that BP in terms of phonetics does not have a unitary literary language, it is found a main difference in the phoneme corresponding to the letters $r$ and $r r$ : in the following groups of words (1) caro 'expensive', prato 'plate'; (2) carro 'car', rua 'street', Israel 'Israel'; (3) mar 'sea', torto 'crooked'; (4) gordo 'fat', 1 group is pronounced as [r], but the remaining groups vary in different regions: in Belo Horizonte 2 and 3 ones are pronounced as [h] and 4 as voiced [ $\mathrm{h}$ ], in Rio de Janeiro 2 and 3 are pronounced as [x] and 4 as voiced [y], in the rural dialect 2 it is pronounced as [ $\breve{\mathrm{r}}$ ], 3 and 4 as [I] (Silva, 2003, p. 51).

This system points out to the consideration of the consonants $[\mathrm{r}]-\left[\mathrm{r}^{\mathrm{j}}\right]$ and $[\mathrm{x}]-\left[\mathrm{x}^{\mathrm{j}}\right]$ as excludent forms in the native language, but it actually does not reflect in the acquired, except in the position of 3, i.e when these phonems occur after the vowel. This way, students from Rio de Janeiro pronounce usaps 'czar' иза $[\mathrm{x}]$, умер 'dead' - уме [x], гордый 'proud' - го[х]дыı̆, артист 'artist' a[X]тист, пример 'example' - приме $[\mathrm{x}]$, яркий 'bright' - я[х]кий, but students from the rural region pronounce гордый 'proud' - го[I] $]$ biй, артист 'artist' - $а[\mathrm{I}]$ тист, горла 'throat' - го[л]ла, горько 'bitterly' - го[л]ко. Thus, the pronunciation of Russian $p$ and $x$ will depend on two factors: 1) the territorial affiliation of the Brazilian student and 2) the position of these phonemes in the syllable and in the word.

Ex. 1. Read the words:

Характер, холодно, ходить, хитрый, хлеб, плохой, Хельсинки, страх, шахматы, воздух.

Ex. 2. Divide in two columns words with the soft and with the hard $\mathrm{x}$ from the previous exercise.

Ex. 3. Read the words:

Работа, рабы, рыба, ресторан, раз, скромно, громко, комар, марка.

$E x .4$. Listen to the teacher reading the given words, write down the letter you hear, $\mathrm{x}$ or $\mathrm{p}$ :

Страх, горла, шахматы, ковёр, комар, воздух, корзина, марка.

$E x$. 5. Listen to the words and write the letters corresponding to $\mathrm{x}$ or $\mathrm{p}$ :

Страх, горло, рынок, шахматы, хаос, ковёр, хитрый, хлеб, комар, воздух, корзина, хватить, рабы, марка.

2. Grammar interference

According to Wagner, "focusing on the language of students is not one of the principles, but the linguodidactic basis of this methodology, on which its individual principles are implemented," i.e the work of a specialist in RFL should be guided by the mother tongue of students. (Wagner, 2001, p. 258) This 
position characterizes the methodology of the national linguistic orientation of teaching the target language or, in other words, the national-oriented approach.

Thus, using a comparative analysis of the grammatical aspects of the RL and BP at the initial stage of learning RFL, the potential difficulties of Brazilian students in learning RFL are revealed.

Learning the grammatical aspects of RFL from scratch begins with the sentence structure with a question about the subject and a demonstrative pronoun (hereinafter referred to as DP): Kmo/ чmo эmo? 'Who/ what is this?', along with which the first nouns are given. The influence of the native language is felt from the very first contact with the grammar of the non-native language, since the student is already faced with the lack of the verb ecmb 'eat' in the Present tense, which is felt from the first lessons when working on these structures. However, the processing of this feature of Russian grammar is already common in not nationally oriented textbooks, as students of different nationalities face this discrepancy with their native language. Therefore, we emphasize the features of the formation of structures with the pronouns эmom 'this', эmo 'this', эта 'this', and эти 'these' in relation to the corresponding BP structures.

The demonstrative pronouns (DP) system is very different in the BP from the RL system. First you have to find out that although the adverbs of place здесь 'here' and aqui 'here' are full equivalents, the adverbs aí 'there' (for the position near the interlocutor), ali 'there' (for the position not far from the speakers) and lá 'there' (for the position far from the speakers) do not have the full equivalent in Russian, where an adverb maм 'there' is used for similar positions. The use of demonstrative pronouns is closely related to the syntactic function of these adverbs. In BP, the pronouns isto 'this', isso 'this' and aquilo 'that' are used in the same way as the RL pronoun эmo 'this' / 'that' is, although the first indicates the position aqui, the second indicates aí, and the third refers to ali or lá. (Cunha, 2008, p. 107-108). In other words, while the BP pronouns indicate the position of the subject, the RL pronoun does not refer to any particular position, but simply reports the fact.

When it comes to DP with the function of an adjective, on the one hand, pronouns in Russian correspond to those positions by which the adverbs of place are determined, that is, the adverb здесь 'here' corresponds to DP эmom (masculine), эта (feminine), это (neuter) and эти (plural), and adverbs man/mym 'there' - mom, ma, mo, and me, according to gender and number. On the other hand, in BP, the constructions equivalent in position of DP form a mirror system with pronouns which have the function of a noun: in the singular, este (masculine) and esta (feminine) for the position of DP isto, esse (masculine) and essa (feminine) for the isso position and aquele (masculine) and aquela (feminine) for the aquilo position. It follows that the systems of Russian DP 
differ depending not only on the indicated position, but also on the syntactic function.

The following exercise may help overcome this difficulty:

The difference between DP system makes possible to understand the errors of Brazilian students in using mo to indicate position:

(1)*То не мой учебник.

*That not my textbook.

'That is not my textbook.'

as well as the distinction between the adverbs aqui and aí sometimes lead to the apprehension of the synonyms здес $b$ and mym 'here' as marks of different positions. The following exercise is proposed to make clear to the students the meaning of Russian DP:

Compare the use of adverbs of place in Russian and in Portuguese.

Это мама. Она здесь. --> Esta é a mãe. Ela está aqui. 'This is mom. She is here.'

Это мама. Она mym. --> Esta é a mãe. Ela está aqui. 'This is mom. She is here.'

Это мама. Она там. --> Essa é a mãe. Ela está aí. / Aquela é a mãe. Ela está está ali. / Aquela é a mãe. Ela está lá. 'This is mom. She is there.'

In addition, the personal pronouns (PP) of $\mathrm{BP}$ are significantly different from RL. In Brazil, eu 'I', você 'you' (o senhor / a senhora for respectful treatment), ele 'he' (ela 'she') are used in singular and nós 'we' (a gente in the informal speech), vocês 'you' (os senhores / as senhoras for respectful treatment), eles 'they' (elas) in the plural for 1st, 2nd and 3rd persons, respectively. From the point of view of the ratio of the personal pronoun and the conjugated verb form, we observe the following system in the BP, taking the example of verb fazer 'to do': (eu) faço, (você, o senhor, ele, a gente) faz, (nós) fazemos and (vocês, os senhores, eles) fazem, i.e in Brazil, the 3rd person verb termination is used to refer to the 2nd (Cunha, 2008, p. 303-305). In this regard, the mixing of grammatical forms in the $\mathrm{BP}$ in the highest degree leads to a greater need to put a personal pronoun in front of the verb, compared to RL, in which a relatively simple system with six PP and six different endings of the verb is noted, taking the example of verb делать 'to do': я делаю, mbl делаешь, он делает, мы делаем, вы делаете и они делают. In addition, the pronoun $\mathrm{Bbl}$ 'you' as a form in the singular of respectful treatment is not simple for a Brazilian student in terms of both meaning and grammar (matching with an adjective: $B$ bl красивая. 'You are beautiful.').

The different PP systems leads to difficulties by Brazilian students to use verbs in the $2^{\text {nd }}$ person and to errors such as

(2) Вы, Наталья Сергеевна, очень умные. 
Medina et al., 2020. Linguistic Errors of Brazilian Students when Learning

Russian as a Foreign Language (Basic Level)

You Natalia Sergeevna very smart; PL

'You, Natalia Sergeevna, are very smart'.

Such errors might be avoided by exercises through which the student understands the correlation between the PP and the verbs and adjectives used with it:

Ex. 1. Complete the missing words according to the example.

Привет, Иван! ... по-итальянски? (говорить) --> Ты говоришь порусски? 'Do you speak Russian?'

Здравствуйте, Иван Сергеевич! ... по-итальянски? (говорить) --> Bbl говорите по-итальянски? 'Do you speak Italian?'

Серёжа, тыл ... . (хороший друг) --> Серёжа, ты хороший друг. 'Seryozha, you are a good friend.'

Сергей Алексеевич, Вы ... . (отличный преподаватель) --> Сергей Алексеевич, Вы отличный преподаватель. 'Sergey Alekseevich, you are a great teacher.'

Other explicit discrepancies include cases and types of verbs. When comparing such aspects, the question arises "What criteria should be used to make a comparison, as absolute equivalents do not exist?". Therefore, the compilation of parallel constructions is carried out using correspondences with cases in word order and the selection of the preposition in BP, and with the types of the verb in the BP auxiliary constructions to determine the equivalent of the verb.

In the analysis of the accusative case of a direct object with a local value, differences from the BP are clearly felt in two aspects: (1) the value of space in the BP is also formed using prepositions, which is intuitively characteristic of the indirect complement for the Brazilian student. (2) On the one hand, the prepositions в and на are used in the accusative and in the prepositional cases for the local meaning, but in that case for the direction to some place and in this to indicate the place of position, which for the Brazilian does not seem natural, so how in BP different prepositions are used for different movements; on the other hand, the Russian prepositions в аnd на are used in opposite situations in the same grammar case, which is also not characteristic of BP. The prepositional case, therefore, also relies on the difference between the prepositions 8 and $\mu a$ 'in' or 'to'.

A construction with the Russian preposition $o$ has the full equivalent with the Brazilian preposition sobre 'about', although it is important to pay attention to the BP multi-functional preposition de 'of' or 'from', which also corresponds to $O$.

Such differences in the movement prepositions result in difficulties to associate the movement to the use of certain grammatical case:

(3) *Я вчера ходил в магазине. 
I yesterday went to the market; PREPOSITIVE

*Yesterday I went in the market.

(4) * Она была в Питер.

She was to Saint Petersburg; ACC

*She was to Saint Petersburg.

We propose to, at first, reinforce the use of the same preposition in different grammatical case and then work on the use of different prepositions to the same movement:

Complete the missing words and indicate the meaning: direction or position.

1. (школа) Иван идет в ... . --> Иван идет в школу. 'Ivan is going to the school.' (направление 'direction')

(школа) Иван находится в ... . --> Иван находится в школе. 'Ivan is currently in the school.' (местонахождение 'position')

2. (школа) Иван идет ... . --> Иван идет в школу. 'Ivan is going to the school.' (направление 'direction')

(школа) Иван находится ... . --> Иван находится в школе. 'Ivan is currently in the school.' (местонахождение 'position')

3. (площадь) Иван едет ... . --> Иван едет на площадь. 'Ivan is going to the square.' (направление 'direction')

The dative case with a local value has an equivalent in BP in certain cases when the direction of movement is determined using the profession. In an indirect object in Russian, the absence of a preposition is noted, in contrast to the use of the prepositions para and a in BP:

(5) Студент дал яблоко преподавателю. - O estudante deu uта тас̧а̃ ao professor./ O estudante deu uma maçã para o professor.

'The student gave an apple to the teacher.'

Another discrepancy is in the complement of verbs: sometimes a verb in Russian requires an indirect object, and the equivalent in Portuguese does not always correspond:

(6) Паииент верит врачу. - O paciente confia no médico. (indirect obj.)

'The patient trusts the doctor.'

(7) Иван помог другу. - Ivan ajudou о amigo. (direct obj.)

'Ivan helped the friend.'

A general comparison with BP equivalents indicates a greater number of phenomena in which the objects of Russian verbs in the dative case have no preposition, while in Portuguese there is a preposition in similar verbs. It is very common to observe the use of the nouns in the Accusative case when the correspondent in BP is direct object. 
Medina et al., 2020. Linguistic Errors of Brazilian Students when Learning Russian as a Foreign Language (Basic Level)

The preposition no 'by' or 'in', in addition to the construction no + language (говорить по-русски), can form different meanings in the dative case; the local value is perceived when compared with the equivalent of BP por 'by':

(8)Иван гуляет по парку. - Ivan passeia pelo $($ por + o) parque.) 'Ivan walks in the park'

Although, the preposition value is already very different in other situations: the preposition is not translated as por, but as em or de in Portuguese (специалист по литературе - especialista em literature 'specialist in literature'; учебник по русскому языку - apostila de língua russa 'textbook of Russian language'). In the meaning of в соответствии 'in accordance', the equivalent in Portuguese is the prepositions conforme or de acordo com 'according to' (по плану - de acordo com o plano/ conforme o plano 'according to the plan'). This leads to mistakes using preposition $в$ as специиалист 8 литературе.

The difficulties associated with the dative case can be overcome through exercises in which it is necessary to avoid the use of preposition, as well as others requiring the use of the right preposition:

Make the sentences:

1. студент+дать +яблоко+преподаватель --> Студент дал яблоко преподавателю. 'The student gave an apple to the teacher.'

Иван +помочь +друг --> Иван помог другу. 'Ivan helped the friend.'

Маша+мешать+брат --> Маша мешает брату. 'Masha disturbs the brother.'

2. он+специалист+литература --> Он специалист по литературе. 'He is specialist in literature.'

это+учебник+русский язык --> Это учебник по русскому языку.

'This is a textbook of the Russian language.'

Let us dwell on the main distinguishing features of the expression of the genitive case. Its more detailed consideration would require a separate section, due to the great diversity of this grammar case. In the meaning of the possessor, the genitive is equivalent in a construction with the preposition de: дом отия a casa do $(\mathrm{de}+\mathrm{o})$ meu pai 'the house of my father'. The construction with the preposition $y+$ the genitive case of animate nouns is a big discrepancy with the corresponding construction in Portuguese:

(9) У меня новая машина. - Eu tenho uт carro novo.

'I have a new car.'

The Russian preposition $y$ is translated into Portuguese as junto $a$ 'together with', which denotes a position very close to the subject, in touch with it. However, the Portuguese equivalent of the construction of the verb ter 'to have' is translated in the same way as the verb uмems 'to have', although not in all cases: 
(10) $\quad$ У меня новая машина./ Я имею новую машину. - Eи tenho ит carro novo.

'I have a new car.'

In the second case, comparing parallel constructions with verbs uмems and ter does not help to understand the meaning of the structure with the preposition $y$.

Ex.1. Make the sentence. Use the verb иметь when it is possible.

я+новая машина --> У меня новая машина. / Я имею машину. 'I have a car.'

отеи+болеть+голова --> У отиа болит голова. 'The father has a headache.'

Teaching the genitive case in negative sentences requires a lot of attention in the teaching process in a Brazilian audience. We have not identified direct correlations with the native language of students.

The instrumental case can be used in the meaning of the subject with the help of which something is done: Я пишу ручкой 'I write with a pen'. In this case, the value in Russian is given only through the noun ending in a certain case, which is impossible in BP; in this language, the equivalent is the construction with the preposition com: Eu escrevo com caneta 'I write with a pen'. However, the same preposition in Portuguese is used in a construction similar to the phenomena of this case with the pretext $c$ : Пельмени с мясом и $c$ каnyстой - Pelméni com carne e repolho 'Pelmeni with meat and cabbage'. In the second case the founded mistakes regard only the word termination, but the first one involves the incorrect use of the preposition $c$ : Я пишу с ручкой.

Make sentences with the separate words.

я+писать + ручка --> Я пишу ручкой.

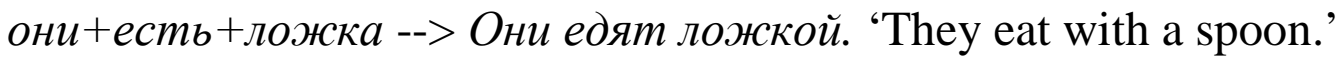

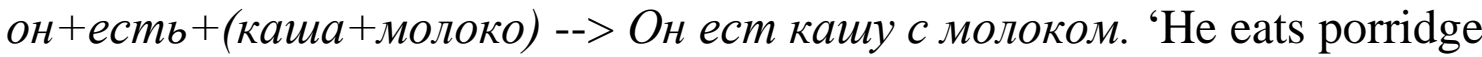
with milk.'

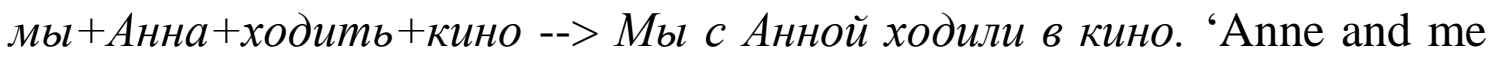
went to the cinema.'

The instrumental case can be used as well as a complement to different verbs. Due to the fact that for a Brazilian student the concept of complement in the native language consists of two types - without a preposition (direct) and with a preposition (indirect), the concept of augmentation in RL is not at all simple: complements in instrumental case occur after certain verbs with a preposition, and after others without. At the initial stage, there is a larger number of complements without a preposition: управлять 'rule', заниматься 'handle', стать 'become', увлекаться 'get carried away' и интересоваться 'take interest in', but there are also complements with preposition: поздравлять 'to congratulate' and встречаться 'to meet'. The first three verbs in BP require 
Medina et al., 2020. Linguistic Errors of Brazilian Students when Learning Russian as a Foreign Language (Basic Level)

complement without a preposition, the next three are used with the preposition por 'by' and the last with the preposition com 'with'. Such a variety of possible equivalents makes it difficult to compose analogues between languages, leading to errors like управлять предприятие instead of управлять предприятием 'rule the company', заниматься спорт instead of заниматься спортом 'practice sports', стать врача instead of стать врачом 'become a doctor', увлекаться с спорт instead of увлекаться спортом 'get involved with sport', интересоваться по спорт instead of интресоваться спортом 'take interest in sport'.

Associated to this we find necessary to work on this discrepancy through the following exercise:

Make sentences:

Иван Сергеевич+управлять +предприятие --> Иван Сергеевич управляет предприятием. 'Ivan Sergeevich rules the company.'

Сама+любить+заниматься+спорт --> Саша любит заниматься спортом. 'Sacha loves to practice sport.'

Маша+хотеть +стать + врач --> Маша хочет стать врачом. 'Masha wants to become a doctor.'

In comparing verb systems, there is a large discrepancy in the types of the Russian verb, which is closely related to their endings. In RL there are three tenses: Past, Present and Future for imperfective verbs and two, Past and Future, for perfective verbs. In comparison with BP, each time of the Russian verb corresponds to different tenses of the Portuguese verb, i.e. the variety of meanings of Russian is partially reflected in Portuguese in the form of different tenses of the verb with separate endings, while in Russian, for each verb, endings are much less varied. This discrepancy is highly significant, because in the language of the Brazilian student different tenses are expected to be used with different endings, and in Russian one meets only two for each verb. To indicate the Past tense, the suffix $-\pi$ in the next sentence corresponds, without taking into account the complex forms of tenses with the auxiliary verb, to two possible endings of Portuguese:

(11) Я учился в университете. --> Eu estudei na universidade./ Eu estudava na universidade. 'I studied in the university.'

This discrepancy is due to the fact that the types of the verb in BP are determined by other rules. In the Indicative mood, Portuguese has three past tense forms: imperfect, simple past and pluperfect; the first is characterized by a punctual action that does not last; the second is a continuous action lasting in the past, the end of which is not known or not important in the oral speech; and the third is an action that occurs in the past before another action. We emphasize that the definition of equivalents of an imperfect type in Portuguese is closely related to the situation of use, especially with adverbs: 
(12) Сегодня я ел мясо. - Eu comi carne hoje.

'I ate meat today.' (simple past in Portuguese)

(13) Раньше я ел мясо. Теперь я вегетарианеи. - Antes еи сотіа carne. Agora, sou vegetariano.

'I used to eat meat. Now I am vegetarian.' (imperfect in Portuguese)

In such cases is very common to find the use the perfective mood when it is not intended: Сегодня я съел мясо. 'Today I ate meat.'; Раньше я съел мясо. 'Previously I ate meat.', which not always are mistakes per se, but result in unintended meanings.

We suggest the reinforcement of the imperfective aspect and only then the work on the perfective aspect:

Complete the missing verbs in the conjugated form.

(1) (есть) Раньше он ... кашу с молоком по-утрам. Теперь он ... только фрукты. --> Раньше он ел кашу с молоком по-утрам. Теперь он ест только фрукты. 'Previously he ate porridge and milk. Now he eats only fruits.'

Он всегда ... фрукты, но вчера он ... кашу с молоком. --> Он всегда ecm фрукты, но вчера он ел кашу с молоком. 'He always eats fruits, but yesterday he ate porridge and milk.'

(2) (есть-съесть) Сегодня утром он ... всю кашу. Поэтому, мы ничего не ... . --> Сегодня утром он съел всю кашу. Поэтому, мы ничего не ели. 'Today in the morning he ate all the porridge. Therefore we didn't eat anything.'

(смотреть-посмотреть / приезжать-приехать) Вчера вечером мы ... фильм, когда Иван ... домой. --> Вчера вечером мы смотрели фильм, когда Иван приехал домой. 'Yesterday in the evening we were watching a film, when Ivan arrived home.’

\section{Conclusions}

For educational purposes, on the basis of linguistic typology and comparative studies between Russian and Brazilian Portuguese, we revealed and described linguistic difficulties that a Brazilian student faces when mastering the Russian phonetic and grammar systems. First, the comparison of the consonant systems of the RL and the BP allows us to predict the potential sound interference in the reproduction of consonants; based on a phonological comparison, significant interference is noted in the signs of hardness, softness, place of articulation and mode of articulation. Second, the grammatical interference is observed in the mastering of subjective personal pronouns of the 2nd person; categories of place, including adverbs and demonstrative pronouns; 3rd position possessive pronouns; correlation of types of complementing the grammatical structure of the RL with prepositions due to the lack of cases and 
Medina et al., 2020. Linguistic Errors of Brazilian Students when Learning

Russian as a Foreign Language (Basic Level)

the different use of prepositions for the formation of the addition of verbs in BP; tenses and types of Russian verbs.

In order to overcome the described difficulties and interference, we suggested the samples of exercises to avoid the linguistic errors. Also, the system of such exercises has further development and is being currently tested by the authors.

\section{References}

Arakin, V.D. (1989). Tipologija jazykov i problema metodicheskogo prognozirovanija. Moskva: Vysshaja shkola.

Bearzotti Filho, P. (2002). Formação linguística do Brasil. Curitiba: Nova Didática, p. 80

Budnik, E.A. (2007). Osobennosti inostrannogo akcenta na baze russko-portugal'skogo dvujazychija studentov Afriki i Latinskoj Ameriki. IX nauchno-prakticheskaja konferencija molodyh uchenyh. Aktual'nye problemy russkogo jazyka i metodiki ego prepodavanija: RUDN, 27 aprelja 2007 goda. Moskva: Flinta: Nauka.

Budnik, E.A. (2009). Lingvodidakticheskie aspekty izucheniya zvukovoi interferencii (na materiale russko-portugalskogo dvuyazychiya) avtoreferat dis. kandidata pedagogicheskih nauk. Ros. un-t druzhby narodov. Moskva: RUDN Publ.

Castro, T. (2005). Fale russo. Porto Alegre: Ediplay.

Cunha, C., \& Cintra, L. (2008). Nova gramática do português contemporâneo. 5a ed. Rio de Janeiro: Lexikon.

Dolenga, M. (1995). A língua russa. Gramática elementar. Edição 2 ed. Local e editora da publicação Rio de Janeiro: Globo.

Gak, V.G. (2006). Russkij jazyk v sopostavlenii s francuzskim: Uchebnoe posobie. Izd. 4-e. Moskva: KomKniga.

Oliveira, B.E. (n. d.). Curso de russo: do básico ao avançado. RussiaNet. Retrieved from http://files.brasilpage.webnode.com.br/200000013-aec4faf3f4/Russo\%20\%20Curso\%20Completo.pdf

Petrova, G.V. (2016). Oshibki uchenikov kak zerkalo strukturnyh razlichij mezhdu portugal'skim i russkim jazykami. // Iberoamerikanskie tetradi. Moskva. 123-137.

Potapova, N. (1961). Breve manual de língua russa. Moskva: Edições em línguas estrangeiras.

Silva, Taís Cristófaro. (2003). Fonética e fonologia do Português: roteiro de estudes e guia de exercícios. / Taís Cristófaro Silva. 7 ed. São Paulo: Contexto, p.51.

Vereshhagin, E.M., \& Kostomarov, V.G. (1990). Jazyk i kul'tura: Lingvostranovedenie v prepodavanii russkogo jazyka kak inostrannogo. Moskva: Rus. jaz.

Wagner, V.N. (2001). Metodika prepodavanija russkogo jazyka anglogovorjashhim i frankogovorjashhim na osnove mezh"jazykovogo sopostavitel'nogo analiza. Moskva: Gumanit izd. centr VLADOS.

Weinreich, U. (1972). Odnojazychie i mnogojazychie. Novoe v lingvistike. Vyp. 6, 25-60. 